\title{
To the Memory of Mikhail Romanovich Shura-Bura
}

DOI: $10.1134 / \mathrm{S} 036176880904001 \mathrm{X}$

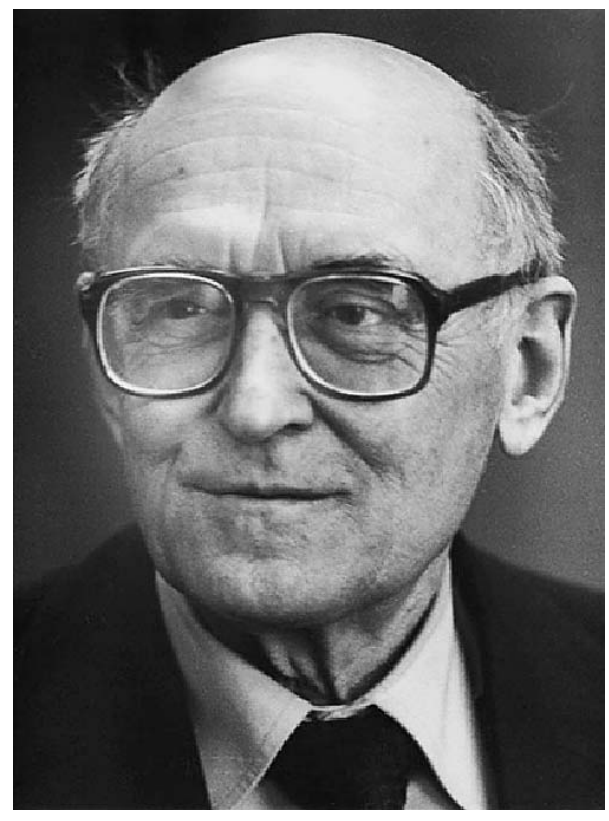

A patriarch of domestic programming, doctor of physico-mathematical sciences, professor, honored worker of science of the Russian Federation, double laureate of the State Prize, honored professor of the Moscow University, permanent member of the editorial board of our journal Mikhail Romanovich ShuraBura died on December 14, 2008 on the ninety first year of his life.

Mikhail Romanovich began his scientific activity as a mathematician. In 1947 he defended a candidate dissertation in topology on the subject "Projection Spectra of Bicompact Spaces". The difficult task of reconstructing a topological space from its spectrum was solved in his work. These results of Mikhail Romanovich were highly appraised by topologists and initiated new researches in this field.

M.R. Shura-Bura began studying the problems of computational mathematics as early as the war years, cooperating with the department of external ballistics of the Artillery Academy named after F. E. Dzerzhinskii. Since 1947 M. R. Shura-Bura started to work at the department of approximate computations of the V. A. Steklov Mathematical Institute of the AS USSR. In 1948 this department was transferred to the Institute of Precision Mechanics and Computer Engineering of the AS USSR. In 1952 he defended a doctoral dissertation The Questions of Solving Mathematical Problems Involving a Large Number of Operations.

Since 1953 M. R. Shura-Bura began working at the Applied Mathematics Department of the V. A. Steklov Mathematical Institute created by M.V. Keldysh and then reorganized into the Institute of Applied Mathematics of the AS USSR (at present it is called Keldysh Institute of Applied Mathematics (IAM) RAS), where he headed the department of programming automation. The first result of the work of the programming department of the IAM that was headed by M.R. Shura-Bura was the development of software for calculating the nuclear explosion energy on the computer "Strela" (1953-1955). The parameters of computers of that time demanded of programmers virtuoso skills and tricks in organizing computations and program debugging. In 1955 M. R. Shura-Bura was awarded the State Prize of the USSR for the contribution to the creation of nuclear weapons. In the mid 1950s, the programming department was attracted by V.M. Keldysh to the calculations of trajectories of artificial Earth satellites. The programs for Strela ensured the round-the-clock mode of trajectory processing. Since 1957 they had been used when launching the first world's satellite, during the flight of Yu.A. Gagarin in 1961 and during the next 10 years.

M.R. Shura-Bura is the co-author of the architecture of the known M20 computer the architecture of which was subsequently used in several series of domestic semiconductor computers; he managed the development of its basic software. Mikhail Romanovich is the author of the interpreting system IS-2, which was famous in due time. The works of the department of M.R. Shura-Bura on programming languages and systems were started as early as the 1950s with the use of operator programming based on the A.A. Lyapunov's theory of program schemes. The first compiler for the complete version of ALGOL 60 was developed under the direction of M. R. Shura-Bura in 1963. The software for BESM-6 and other types of computers followed them.

M. R. Shura-Bura was a scientific director of the development of software for the Soviet line of computers ES EVM. In 1978 he was awarded the State Prize of the USSR for accomplishing this work. M. R. ShuraBura made a decisive contribution to developing the software of the control system of the orbital spaceship Buran. To overcome the principal difficulties that called into question the possibility of successfully 
completing the works, M. R. Shura-Bura suggested a new technology of program development based on the use of high-level problem-oriented programming languages. He was awarded the Lenin Order for the contribution to the creation of Buran.

Mikhail Romanovich devoted much attention to training scientific specialists. In the war years and till 1947, Mikhail Romanovich worked as a teacher of the mathematics department in the Dzerzhinskii Artillery Academy. In 1955, he became a professor of Moscow State University, and in 1995 he was conferred the title of the honored professor of the Moscow University. Tens of candidate and doctoral dissertations were prepared and defended under his supervision. M. R. ShuraBura is a creator and head of the leading scientific school in the field of programming. He fruitfully worked at Moscow University for more than half a century. Many domestic programmers of the elder generation either attended his unique lectures on the problems of programming at the department of mathematics and mechanics or studied using his monographs and textbooks on programming. The first Soviet Union monograph on programming that was written by M.R. Shura-Bura in co-authorship with L.A. Lyusternik, A.A. Abramov, and V.I. Shestakov in 1952 (Solution of Mathematical Problems on Automatic Digital Machines:. Programming for HighSpeed Computers. Moscow: Izd. AN SSSR, 1952) is known to practically any representative of the first generation of domestic scientists.

When the department of Computational Mathematics and Cybernetics of Moscow State University was created in 1970, M. R. Shura-Bura became an organizer and chief of the system programming chair and headed it till 1993. He was an outstanding teacher and witty, brilliant lecturer. He gave a whole series of fundamental and special courses on the modern problems of software engineering, his numerous students work at many organizations in Russia and abroad (in China, Germany, Bulgaria, Hungary); among them, there are famous scientists, doctors and candidates of sciences. Mikhail Romanovich also considerably influenced the formation of the team of system programmers in the Computing Center of Moscow University. The research seminar on programming automation that was organized by him in 1956 is well known in Russia and states of the former Soviet Union-dissertations of many leading specialists in system programming were approved at this seminar.

M. R. Shura-Bura was a permanent member of the editorial board of the journal Programmirovanie since the date of its foundation. His attentive and witty notes, benevolent advices to authors determined the scientific level of the published articles in many respects.

The cherished memory of Mikhail Romanovich Shura-Bura who was a rarely talented scientist, excellent manager and benevolent man will remain in our hearts forever.

The Editorial Board of the Journal

Programmirovaniye (Programming and Computer Software) 